\title{
Korkeatuottoisten emakoiden kuitupitoinen ruokinta
}

Sini Perttilää), Heidi Högel ${ }^{2)}$, Mika Kurkilahti ${ }^{3)}$, Jarkko K. Niemi ${ }^{4)}$, Susanna Särkijärvii ${ }^{2)}$, Hilkka Siljander-Rasi ${ }^{5)}$, Niina Immonen ${ }^{6}$, Kimmo Kytölä6), Soile Kyntäjä6) ja Venla Virtanen ${ }^{7)}$

${ }^{1)}$ Luonnonvarakeskus, Latokartanonkaari 9,007901 Helsinki, sini.perttila@luke.fi

${ }^{2)}$ Luonnonvarakeskus, Tietotie 4, 31600 Jokioinen, etunimi.sukunimi@luke.fi

${ }^{3)}$ Luonnonvarakeskus, Itäinen Pitkäkatu 4, 20520 Turku,mika.kurkilahti@luke.fi

4)Luonnonvarakeskus, Kampusranta9c,60120 Seinäjoki, jarkko.niemi@luke.fi

${ }^{5)}$ Finnpig Oy, PL 117, 60101 Seinäjoki, hilkka.siljander-rasi@finnpig.fi

${ }^{6)}$ A-Tuottajat Oy/A-Rehu Oy, Itikanmäenkatu 3, Seinäjoki,60060 ATRIA, etunimi.sukunimi@atria.com

${ }^{7)}$ Helsingin Yliopisto, Maataloustieteiden laitos, PL 28,00014 Helsinki,venla.virtanen@helsinki.fi

\section{TIIVISTELMÄ}

Tilaseurannassa selvitettiin imetysrehun korkeamman kuitupitoisuuden vaikutuksia emakoiden kuntoon, rehunkulutukseen, kiimaan tuloon, imevien porsaiden kasvuun sekä vieroitettavien porsaiden määrään ja laatuun ohravalkuaisrehu-pohjaisella liemiruokinnalla.

Tutkimuksessa seurattiin yhteensä 80 emakkoa ja niiden porsaita porsitustilalla. Imetysrehuista kontrollirehu sisälsi ohraa, vehnää, kauraa, ohravalkuaisrehua, kasviöljyä sekä täydennysrehua, johon ei ollut lisätty erillisiä kuidun lähteitä. Kontrollirehussa oli noin 4\% raakakuitua kuiva-aineessa ja noin 15\% NDF-kuitua kuiva-aineessa. Koerehussa kauran osuutta lisättiin ja täydennysrehu sisälsi erillisiä kuidunlähteitä, kuten ohrakuiturehua ja sokerijuurikasleikettä. Koerehussa oli noin $7 \%$ raakakuitua kuiva-aineessa ja noin 18\% NDF-kuitua kuiva-aineessa. Rehujen energiaväkevyys oli sama (11.2 ja $11.3 \mathrm{MJ} \mathrm{kg}^{-1} \mathrm{ka}$ ). Emakot ruokittiin neljä kertaa päivässä ohjeellisen ruokintakäyrän mukaisesti, ja rehunkulutusta seurattiin ruokintalaitteelta venttiileittäin. Emakot punnittiin ja niiden selkäsilava mitattiin porsitusosastolle tullessa ja vieroitettaessa. Porsaat punnittiin emakkokohtaisesti pahnueen tasauksen jälkeen sekä vieroitettaessa. Emakoiden ulostamista, ummetusta ja ulosteiden laatua tarkkailtiin porsitusosastolla kolme päivää ennen ja viisi päivää jälkeen porsimisen. Porsaiden ripulin esiintymistä tarkkailtiin hoitotoimien yhteydessä.

Emakoiden painoissa ei ollut merkitseviä eroja ruokintaryhmien välillä. Niiden painon menetys oli keskimäärin $31 \mathrm{~kg}$ ja silava oheni $3.7 \mathrm{~mm}$ siirtopäivästä vieroitukseen. Emakoiden tiinehtymisessä ei havaittu eroja ryhmien välillä, ja suurin osa $(75 \%)$ emakoista tiinehtyi viikon sisällä vieroituksesta. Porsaiden kokonaislukumäärissä, elävänä syntyneiden tai vieroitettujen porsaiden määrissä ja porsaiden kasvuissa ei havaittu eroja ruokintaryhmien välillä. Kokonaisrehunkulutus kokeen aikana emakkoa kohti oli 1995 MJ NE eikä ryhmien välillä havaittu merkitsevää eroa rehunkulutuksessa. Porsaiden lisäruokintatiedot eivät viitanneet eroihin emakon maidontuotannossa. Ainoa merkitsevä ero ryhmien välillä oli silavan ohentumisessa imetysaikana viidettä kertaa porsineilla emakoilla. Ero oli pieni ja viidettä kertaa porsineiden emakoiden määrä pieni (4 kpl per ryhmä), mutta sillä on mahdollisesti merkitystä emakon kunnostuksessa eli rehunkulutuksessa ja palautumisessa seuraavan alkutiineyden aikana. Tuotostasoissa ei ollut eroja käsittelyiden välillä, joten katetuoton ratkaisee rehun hinta.

Tutkimuksessa todettiin, että tuotantosikalan olosuhteissa voidaan tehdä luotettavaa rehututkimusta. Tilastollisten analyysien perusteella havaintojen määrä oli pieni ja/tai hajonnan määrä oli suuri, joten tutkimuksen suunnitteluun, havaintojen määrään ja tiedonkeruun yksityiskohtiin täytyy kiinnittää erityistä huomiota tulosten varmistamiseksi.

Asiasanat: emakko, kuitu, imetysrehu, tuotanto, tilatutkimus 


\section{Johdanto}

\section{Emakon tiineysajan ruokinta}

Perusta ja edellytykset emakon onnistuneelle imetyskaudelle luodaan tiineyden aikana. Rehun sisältämällä kuidulla voidaan osaltaan vaikuttaa emakoiden hyvinvointiin, kunnon säätelyyn ja sitä kautta porsimisen ja imetyksen onnistumiseen. Emakoiden oikea kuntoluokka (tavoite 3.0-3.5) porsiessa on yksi onnistuneen imetyskauden edellytyksistä. Emakoiden kunnostus tavoitekuntoon tehdään alkutiineyden aikana (Luke 2015). Emakoiden energiansaantia rajoitetaan tiineyden lopulla, jotta ne eivät lihoisi liikaa. Tiineiden emakoiden energian saannin rajoittaminen rehuannosta pienentämällä ei yleensä tuota riittävää kylläisyyden tunnetta, mikä lisää emakoiden stereotyyppisiä käyttäytymishäiriöitä. Tiineiden emakoiden energian saantia voidaan rajoittaa korvaamalla viljaa kuitupitoisilla rehujakeilla tai antamalla emakoille runsaasti karkearehua perusrehun lisäksi (Ramonet ym. 1999). Runsaasti kuitua sisältävän rehun käyttö tiineysaikana edistää emakon imetysrehun syöntiä porsimisen jälkeen (Guillemet ym. 2010). Kuitu parantaa ruuansulatuskanavan kapasiteettia ja toimintaa, ja siksi tiineysaikana kuitua syöneet emakot pystyvätkin syömään enemmän rehua (ja myös kuitua) imetyskaudella (Matte ym. 1994, Veum ym. 2009). Che ym. (2011) tutkimuksessa korkean kuitupitoisuuden rehua tiineysaikana syöneet emakot menettivät vähemmän selkäsilavaa maidontuotannon aikana kuin alhaisen kuitupitoisuuden rehua syöneet emakot, kun kuitulähde sisälsi sekä sulavaa että sulamatonta kuitua.

\section{Emakon porsimisajan ja imetyskauden ruokinta}

Porsimisen yhteydessä emakon kuidun saanti edistää suolen toimintaa, lisää veden juontia sekä ehkäisee ummetusta ja mahdollisesti myös maitokuumeen eli MMA:n (Mastitis Metritis, Agalactia) esiintymistä (Sarandan ym. 2008, Oliviero ym. 2009, Oliviero ym. 2010). Tiineyden aikana ruokinnassa käytettävä rehu vaihdetaan energia- ja valkuaispitoisempaan imetyskauden rehuun yleensä noin viikko ennen porsimista, kun emakot siirretään porsituskarsinoihin. Imetysaikana emakoiden rehun energiapitoisuus on saatava tiineysrehuun verrattuna korkeaksi, jolloin rehun kuitupitoisuus väistämättä pienenee. Energiapitoisen ja samalla vähäkuituisen imetysrehun syöttäminen lisää ummetuksen todennäköisyyttä. Voimakas ummetus voi liikalihavuuden tavoin pitkittää emakoiden porsimista ja vähentää syöntiä porsimisen jälkeen (Tabeling ym. 2003, Oliviero ym. 2010). Lievä ummetus on tavanomainen tila suoliston toimintojen hiljentyessä elimistön valmistuessa tulevaan porsimiseen, mutta kuitupitoinen ruokinta aktivoi suolen toimintaa. Ummetus on myös yhteydessä utaretulehduksiin. Kuidun syöminen lisää hyvänlaatuisten bakteerien toimintaa suolistossa tuottaen enemmän lima-aineita (musiini), jotka suojaavat suolen pintaa bakteereilta, ja taudinaiheuttajien on vaikeampi kiinnittyä suolen seinämiin ja jäädä elimistöön (Sarandan ym. 2008, Oliviero ym. 2009). Kuitupitoisella ruokinnalla ulosteen laatu on parempi ja jo tiineysaikana elimistön valmistautuessa maidon tuotantoon, nesteen imeytyminen elimistöstä lisääntyy, porsaat kasvavat paremmin ja syntymäpainot nousevat (Oliviero ym. 2009). Kuitupitoisen rehun merkitystä emakon maidontuotannon aikana on tutkittu vain vähän. Oliviero ym. (2009) mukaan kuitulisän positiivinen vaikutus jatkuu jopa kolme päivää kuidun antamisen lopettamisen jälkeen (maidontuotannon alettua). Imetyskaudella lisääntynyt juodun veden määrä lisää maidontuotantoa, jolloin porsaat kasvavat paremmin ja ovat painavampia vieroituksessa (Matte ym. 1994, Veum ym. 2009).

\section{Kuidun käyttö ruokinnassa ja tutkimuksissa}

Kuitulisiä käytettäessä rehuseoksen energia-arvo helposti pienenee, mikä asettaa haasteita imetysrehun kuitulisien valinnalle ja rehun kuitupitoisuudelle. Porsimisen yhteydessä esiintyvän ummetuksen vähentämiseen on riittänyt kuitenkin melko maltillinen kuitupitoisuuden nosto kuten rehun viljan vaihtaminen vehnästä ohraan, jolloin rehun raakakuitupitoisuus on noussut $30 \mathrm{~g} \mathrm{~kg}^{-1}$ pitoisuudesta 60 $\mathrm{g} \mathrm{kg}^{-1}$ pitoisuuteen. Kuitupitoisuuden nostaminen kuitulähteillä $100 \mathrm{~g} \mathrm{~kg}^{-1}$ pitoisuuteen ei kuitenkaan tuonut lisähyötyä, kun ummetusta arvioitiin sonnan kuiva-ainepitoisuuden perusteella (Tabeling ym. 2003). Toisaalta Oliviero ym. (2009) kokeessa, mm. ohraa, kauraa ja vehnälesettä sisältävän tiineysrehun antaminen (70 $\mathrm{g} \mathrm{kg}^{-1}$ raakakuitua) porsimisen aikana vähensi ummetusta verrattuna imetysrehuun, jossa näitä korvattiin mm. vehnällä ja kuoritulla kauralla (38 g kg$~^{-1}$ raakakuitua). 


\section{Sikatutkimusta käytännönläheisesti}

Useimmissa tutkimuksissa kuitupitoista ruokintaa on tutkittu kuivaruokinnalla. Liemiruokinnassa kuitu imee nestettä jo sekoitusvaiheessa ja voi käyttäytyä suolistossa eri tavoin kuin kuivasta rehusta saatu kuitu. Kuivien lisärehujen antaminen erikseen kaukaloon on työlästä, joten kuidun lähteiden tulisi olla osana liemirehuseosta. Kuitulähteiden lajittuminen ja kulku putkistoissa ja venttiileissä tuo omat haasteensa ruokintaan.

Tutkimus oli osa Käytännön läheinen tutkimus sikatilalla -hanketta. Tutkimuksen tavoitteena oli selvittää tilaolosuhteissa, miten kuitulähteitä voidaan käyttää imettävän emakon korkealle tuotostasolle optimoidussa liemiruokinnassa ja miten niiden käyttö vaikuttaa emakoiden kuntoon, rehunkulutukseen, kiimaan tuloon, maidontuotantoon, imevien porsaiden kasvuun sekä vieroitettavien porsaiden määrään ja laatuun sekä taloudelliseen kannattavuuteen. Lisäksi pyrittiin selvittämään ruokintojen vaikutusta emakoiden hyvinvointiin (ummetus). Tavoitteena oli myös rakentaa käytännönläheisen ruokintatutkimuksen koetoimintamalli porsitusosastolle.

\section{Aineisto ja menetelmät}

Tutkimus toteutettiin sikatilalla Kauhajoella 15.1.-17.5.2018. Kokeessa oli kaksi ruokintaryhmää:

1. Kontrolliruokintana oli imetyskauden liemiruokinta: ohravalkuaisrehu (OVR), vilja (ohra, vehnä, kaura) ja täydennysrehu, johon ei ollut lisätty erillisiä kuidun lähteitä. Rehussa oli noin $4 \%$ raakakuitua kuiva-aineessa ja noin 15\% NDF-kuitua kuiva-aineessa.

2. Koeruokintana oli imetyskauden liemiruokinta: ovr, vilja (ohra, vehnä, kaura), kasviöljy ja täydennysrehu, johon oli lisätty erillisiä kuidun lähteitä, kuten ohrarehua tai sokerijuurikasleikettä. Rehussa oli noin 7\% raakakuitua kuiva-aineessa ja noin 18\% NDF-kuitua kuiva-aineessa.

Koe-eläiminä kokeessa oli 80 risteytysemakkoa (40 emakkoa/koeryhmä). Emakot jakautuivat viiteen eri porsitusryhmään tilalla (20 emakkoa/osasto, joista 1-2 emakkoa/osasto oli imettäjäemakoita, jotka eivät osallistu kokeeseen). Emakot siirtyivät tilan normaalista tiineysajan rehusta koesuunnitelman mukaisille imetysrehuille porsitusosastolle siirrettäessä noin viikko ennen porsimista. Vieroituksen jälkeen emakot siirrettiin siemennysosastolle tilan normaalille ruokinnalle. Emakoiden kiimaan tulo ja siemennyksen onnistuminen seurattiin. Emakoiden keskimääräinen porsimiskerta oli 3.4 kontrolli- ja 3.2 koeryhmässä. Pahnueiden porsaat tasattiin 3 . pv syntymästä mennessä osastolla koeryhmän sisällä siten, että emakoilla oli vähintään 14 tasakokoista porsasta. Porsaat vieroitettiin tilan käytännön mukaisesti, jolloin emakoiden koeruokinta päättyi.

Sikalan ruokintalaitteisto (Pellon Group Oy:n FeedFlow) mahdollisti kahden eri rehun jaon imetysosastolla samaan aikaan. Rehut suunniteltiin täyttämään sikojen ravinnontarve (Luke 2014). Porsaat saivat porsasrehua imetyksen aikana sikalan normaalin käytännön mukaan. Päivittäin annetut rehumäärät kirjattiin muistiin pahnueittain. Rehujen raaka-aineista (ohra, vehnä, kaura, kontrolli- ja koetiiviste) otettiin rehunäytteet. Kokeen aikana otettiin ovr:stä eräkohtaiset näytteet rehutehtaalla, jotka analysoitiin siellä. Liemirehuseoksista otettiin näytteitä tilalla kokeen aikana. Emakot punnittiin ja selkäsilava mitattiin porsitusosastolle tullessa ja vieroitettaessa. Porsaat punnittiin pahnueen tasauksen jälkeen, kahden viikon iässä ja vieroitettaessa emakkokohtaisesti. Emakoiden ulosteiden laatu kirjattiin porsitusosastolla kolme päivää ennen ja viisi päivää jälkeen.

Emakoiden paino ja kasvu sekä silavan mittaustulokset laskettiin emakkokohtaisesti. Vastaavasti pahnueiden paino ja kasvu laskettiin pahnuekohtaisesti. Koe- ja kontrolliryhmän välisiä eroja analysoitiin SAS-ohjelmiston (versio 9.4) GLIMMIX- ja LIFETEST-proseduureilla. Valtaosa muuttujista (paino- ja kasvumuuttujat, tarjottu rehumäärä) analysoitiin lineaarisilla sekamalleilla (GLM, Stroup 2012). Lisäksi malleihin otettiin mukaan muuttujista riippuen erilaisia kovariaatteja. Vain tilastollisesti merkitsevät kovariaatit jätettiin lopulliseen malliin. Havaintoyksikkönä kaikissa analyyseissä oli emakko tai pahnue, 40 havaintoa/kontrolliryhmä ja 40 havaintoa/koeryhmä. Laskennasta poistetut emakot hylättiin poikkeavina havaintoina residuaalitarkastelun perusteella. 
Taloudellista tarkastelua varten laadittiin porsastuotannon katetuottolaskelma. Laskelmissa käytetyt emakoiden tuotostasot, rehun kulutus- ja terveystiedot sekä porsaiden tuotantotulokset kerättiin sikalassa kokeeseen osallistuneista karsinoista ja tuotantotulosten analyysien tuloksista. Koska porsastuotannon katetuotto ja porsaan yksikkötuotantokustannus muodostuvat monien eri tekijöiden yhteisvaikutuksesta, laskettiin katetuotto ja tuotantokustannus eri tunnuslukujen yhdistelmänä, ja koeja kontrollikäsittelyn välinen tuottoero arvioitiin tuotettua porsasta kohti. Laskelmissa käytetyt hinnat edustivat vuoden 2018 hintatasoa.

\section{Tulokset}

\section{Rehut ja ruokinta}

Koerehuseoksen analysoitu NDF- ja raakakuitu pitoisuus olivat suunnitellusti suuremmat kuin kontrollirehujen (180 vs 139 ja 65 vs $46 \mathrm{~g} \mathrm{~kg}^{-1} \mathrm{ka}$ ) (Taulukko 1).

Taulukko1. Rehuseosten analysoitu koostumus ja lasketut rehuarvot (suluissa suunniteltu).

\begin{tabular}{|c|c|c|}
\hline & Kontrollirehu & Koerehu \\
\hline Kuiva-aine, $\%$ & 25.5 & 26.1 \\
\hline \multicolumn{3}{|l|}{ Kuiva-aineessa, $\mathrm{g} \mathrm{kg}^{-1}$} \\
\hline Raakavalkuainen & $195(181)$ & $193(181)$ \\
\hline Raakarasva & $39(36)$ & $61(68)$ \\
\hline Raakakuitu & $46(42)$ & $65(65)$ \\
\hline NDF-kuitu & $139(153)$ & $180(201)$ \\
\hline ADF-kuitu & 52 & 67 \\
\hline \multicolumn{3}{|l|}{ Kivennäiset, $\mathrm{g} \mathrm{kg}^{-1} \mathrm{ka}$} \\
\hline Fosfori & 6.9 & 6.8 \\
\hline Kalsium & 8.2 & 8.5 \\
\hline \multicolumn{3}{|l|}{ Lasketut rehuarvot } \\
\hline Sulava raakavalkuainen, $\mathrm{g}(\mathrm{MJ} \mathrm{NE})^{-1}(14.2)$ & 13.8 & 13.0 \\
\hline NE MJ $(\mathrm{kg} \mathrm{ka})^{-1}(11.2)$ & 11.2 & 11.3 \\
\hline Sulava lysiini, g (MJ NE) ${ }^{-1}(0.88)$ & 0.83 & 0.81 \\
\hline Sulava metioniini+kystiini g (MJ NE) $)^{-1}(0.53)$ & 0.51 & 0.53 \\
\hline Sulava treoniini $\mathrm{g}(\mathrm{MJ} \mathrm{NE})^{-1}(0.57)$ & 0.54 & 0.56 \\
\hline
\end{tabular}

$\mathrm{ADF}=$ acid-detergent fiber, $\mathrm{NDF}=$ neutral-detergent fibre, $\mathrm{NE}=$ nettoenergia

Rehutulokset kertovat emakoille tarjotun (=ruokintalaitteen jakaman) rehumäään. Tulosten laskennassa käytettiin rehuaineiden ja rehuseosten kemiallisten analyysitulosten ja ruokintalaitteelta saatujen rehuaineiden määrien $(\mathrm{kg})$ perusteella laskettuja energiamääriä $\left(\mathrm{MJ} \mathrm{NE}_{\text {aik }}\right)$. Rehuseosten ja rehuaineiden energia-arvot laskettiin Evapig ${ }^{\circledR}$-ohjelmalla. Annettujen rehujen määrissä ( $\mathrm{MJ} \mathrm{NE}_{\text {aik}}$ ) emakkoa kohti päivässä ei ollut ryhmien välillä eroja koko kokeen aikana $(\mathrm{p}=0.365)$.

\section{Emakoiden paino}

Emakoiden painoissa siirtopäivänä $(p=0.676)$ tai vieroituksessa $(p=0.193)$ ei ollut eroja ryhmien välillä. Emakot menettivät siirrosta vieroitukseen keskimäärin noin $31 \mathrm{~kg}$. Rehuryhmien välinen painovertailu siirtopäivänä ja vieroituksessa on esitetty Kuvassa 1. 


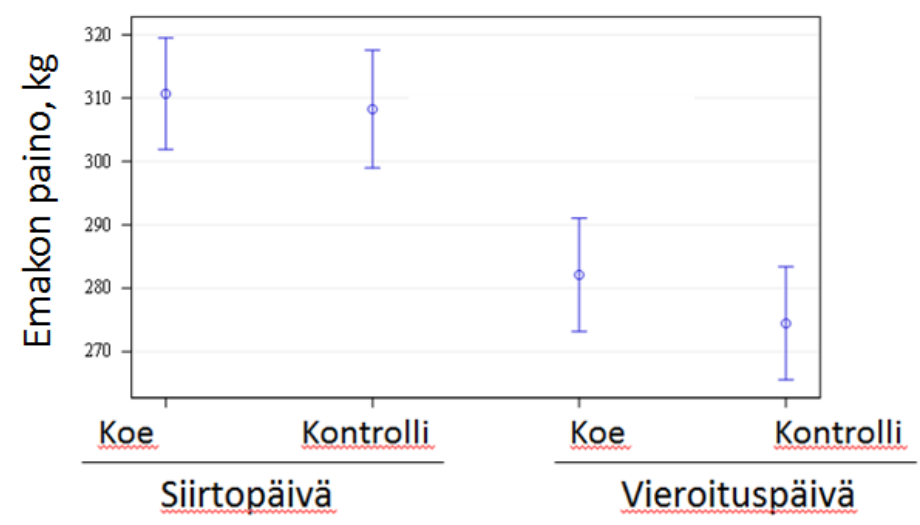

Kuva 1. Emakoiden paino (kg) siirtopäivänä ja vieroituksessa

\section{Emakoiden silavan paksuus}

Emakon silavan paksuudessa ei ollut eroa ryhmien välillä siirtopäivänä $(\mathrm{p}=0.600)$ eikä vieroitettaessa $(\mathrm{p}=0.090)$. Molemmilla rehuilla silava oheni, koko imetyksen aikana keskimäärin $3.7 \mathrm{~mm}$ (Kuva 2). Viidettä kertaa porsineilla emakoilla silava oheni enemmän koeryhmässä kuin kontrolliryhmässä (noin $0.12 \mathrm{~mm} \mathrm{pv}^{-1}, \mathrm{p}=0.013$ ) (Kuva 3).

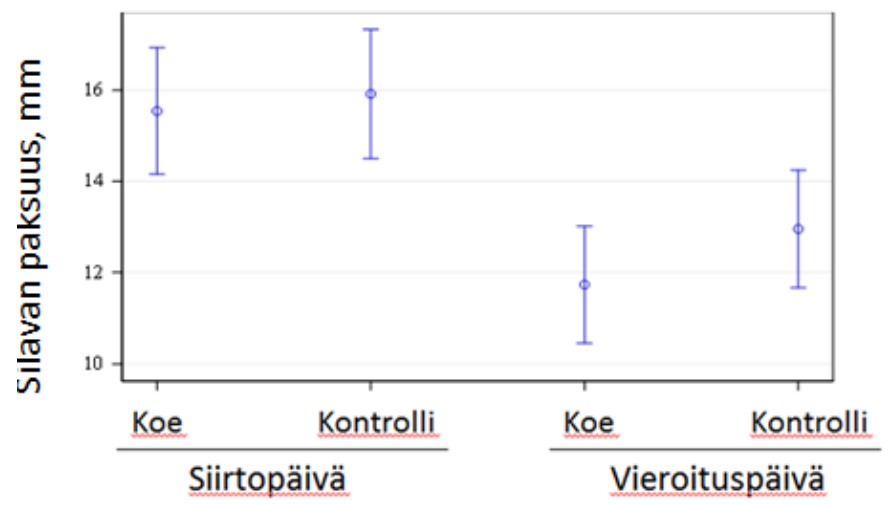

Kuva 2. Emakoiden silavan paksuus $(\mathrm{mm})$ porsitusosastolle siirtopäivänä ja vieroituksessa koe- ja kontrollirehuryhmissä

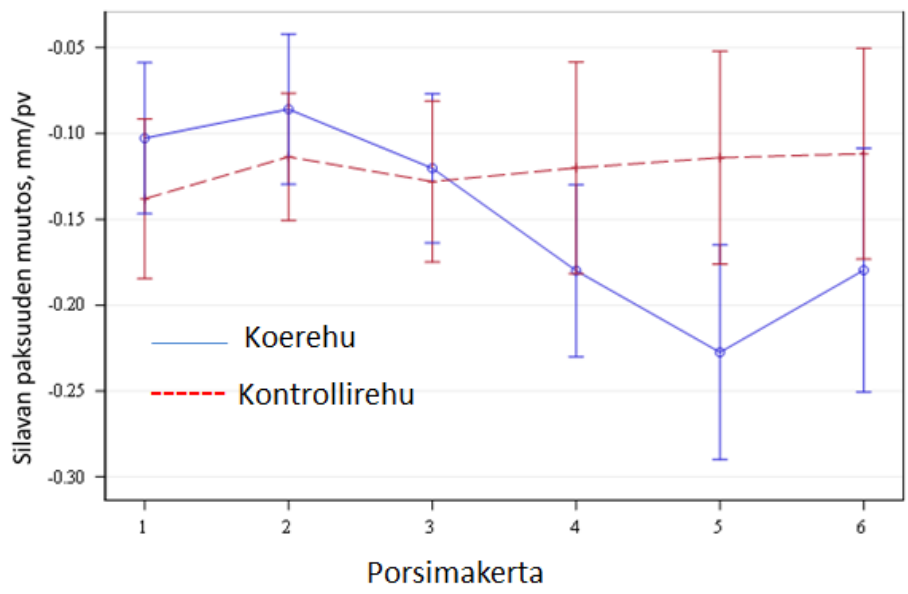

Kuva 3. Emakoiden silavan paksuuden muutos porsitusosastolle siirtopäivän ja vieroituksen välillä $\left(\mathrm{mm} \mathrm{pv}^{-1}\right)$ eri porsimakerran emakoilla koe- ja kontrollirehuryhmissä 


\section{Tiineytys}

Seuraava tiineys katsottiin alkaneeksi viimeisestä siemennyksestä. Molempien ruokintaryhmien emakoista $75 \%$ siemennettiin viimeisen (ainoan) kerran viikon sisään vieroituksesta $(\mathrm{p}=0.678)$.

\section{Porsaiden määrä, painot ja kasvu}

Vieroitusikä oli kontrolliryhmässä 23-34 päivää (mediaani=27) ja koeryhmässä 21-35 päivää (mediaani=27). Kontrolli- ja koeryhmien emakoiden pahnueiden painot ja kasvut eivät eronneet tilastollisesti merkitsevästi ( $p>0.05)$ tasauspäivänä, kahden viikon iässä, eivätkä vieroituksessa. Syntyneiden, elävänä syntyneiden, tasattujen, 2 viikon ikäisten tai vieroitettujen porsaiden määrissä tai painoissa ei ollut eroja koeryhmien välillä ( $\mathrm{p}>0.05$ ). Porsaat kasvoivat koko kokeen aikana $239 \mathrm{~g} \mathrm{pv}^{-1}$ kontrolli- ja $232 \mathrm{~g} \mathrm{pv}^{-1}$ koeryhmässä. Ryhmien välillä ei ollut tilastollisesti merkitsevää eroa myöskään kasvussa $(\mathrm{p}>0.05)$.

\section{Emakoiden ummetus}

Sontimishavainnot porsimisen jälkeen saatiin 31 kontrolli- ja 25 koeryhmän emakolta. Emakoista suurin osa sonti ensimmäisen kerran 1-2 päivää porsimisen jälkeen (Kuva 4); kontrolliryhmän emakoista hieman suurempi osa kuin koeryhmän emakoista (17 vs $12 \mathrm{kpl}, 55 \%$ vs $48 \%$ ). Toisaalta huomattavasti suurempi osa kontrolliryhmän emakoista kärsi ummetuksesta 1-2 päivää porsimisen jälkeen (7 vs 3 kpl, 23\% vs 12\%) (Kuva 4). Kontrolliryhmässä ummetushavaintoja oli runsaasti (6 kpl, $19 \%$ ) vielä viisi päivää tai enemmän porsimisen jälkeen.

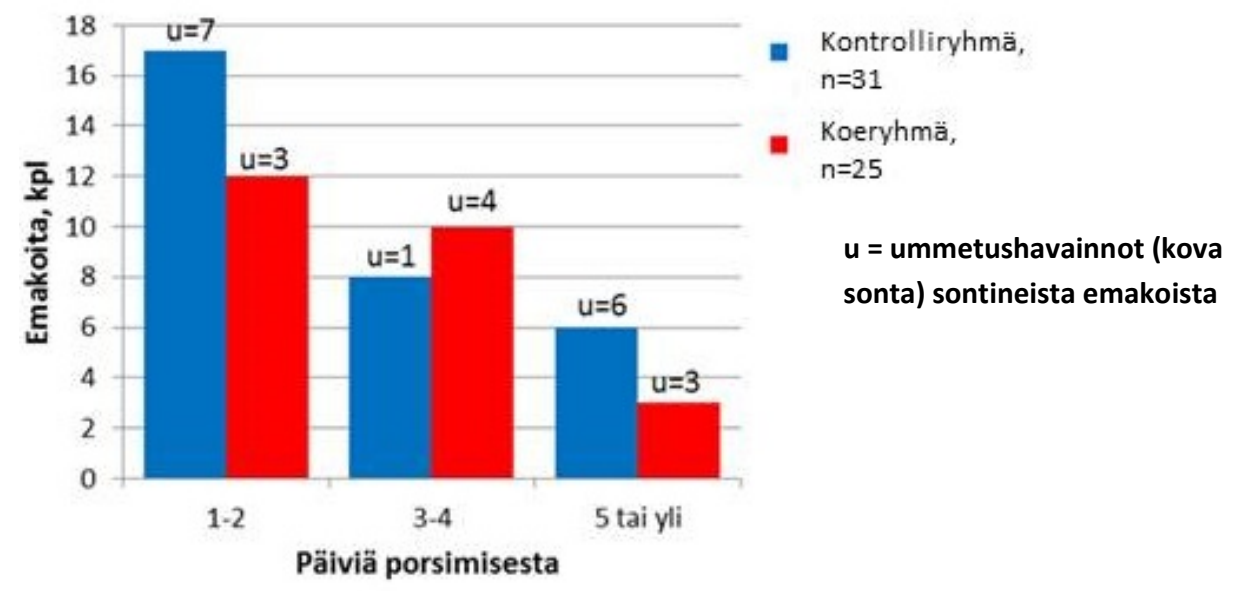

Kuva 4. Emakoiden ensimmäisen sontimisen ajankohta porsimisen jälkeen (pv) ja ummetushavainnot (kpl) emakoista

\section{Katetuotto}

Kuvassa 5 on esitetty koe- ja kontrollirehukäsittelyn välinen erotus katetuotossa, joka on saatu ryhmien keskimääräisillä tunnusluvuilla. Peruslaskelmassa ero on keskimäärin vain muutamia kymmeniä senttejä tuotettua porsasta kohti, mutta koska eri tunnuslukujen erot eivät ole tilastollisesti merkitseviä ja niihin sisältyy melko paljon vaihtelua, ei myöskään katetuottoero ole merkitsevä. Mahdollinen tuottoero näyttää tämän koeaineiston tulosten mukaan aiheutuvan lähinnä rehun hintaeroista käsittelyiden välillä, sillä tuotostasoissa ei tässä kokeessa havaittu eroja kontrolli- ja koekäsittelyn välillä. Rehun hintaero puolestaan johtuu lähinnä koe- ja kontrollirehujen sisältämien rehuaineiden ja niiden pitoisuuksien eroista, joten herkkyysanalyysissä keskityttiin rehun hintaan. Tuottoero kasvaa koekäsittelyn hyväksi, mikäli koekäsittelyn täydennysrehu on edullisempaa kuin kontrollin täydennysrehu. Eron tulisi kuitenkin olla huomattava, jotta tuottoero olisi merkittävä. Myös imetysrehun hintatason nousu parantaa hieman koerehun käytön kannattavuutta. 


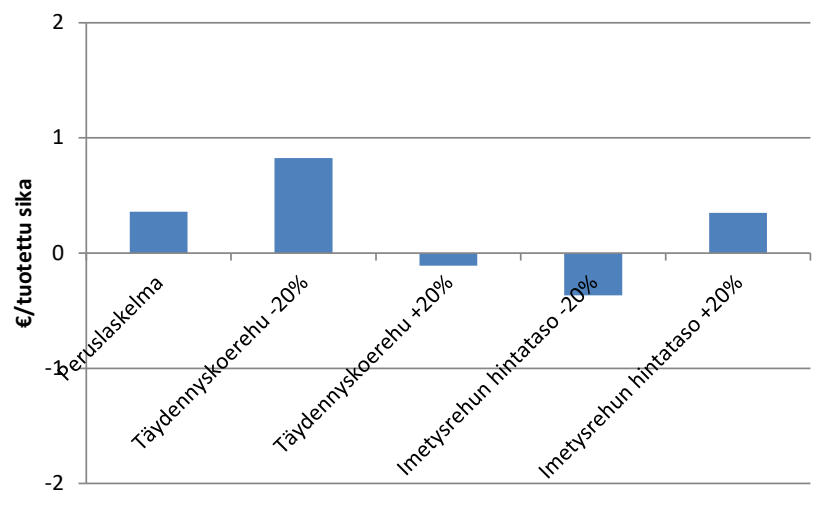

Kuva 5. Koekäsittelyn nettotuoton erotus kontrollikäsittelyyn verrattuna (€ per tuotettu porsas) peruslaskelmassa ja viidessä rehun hintaan liittyvässä herkkyysanalyysin skenaariossa

\section{Tulosten tarkastelu}

Koe- ja kontrollirehujen raakakuitupitoisuuden ero oli tutkimuksessa noin $19 \mathrm{~g}$ kuiva-ainekiloa kohti. Aikaisemmissa tutkimuksissa raakakuidun määrää on nostettu reilummin $\left(+30 \mathrm{~g} \mathrm{~kg}^{-1} \mathrm{ka}\right)$ (Oliviero ym. 2009). Che ym. (2011) jaottelun mukaan koerehumme edusti keskimääräistä kuitupitoisuutta. Koerehu sisälsi enemmän liukoisen kuidun lähteitä (sokerijuurikasleike, kaura, ohrarehu) verrattuna kontrollirehuun. Koerehun NDF-kuidun pitoisuus nousikin kuitulisillä 180 grammaan kilossa kuivaainetta. ADF-kuidun pitoisuus sen sijaan nousi vaan hiukan $\left(+15 \mathrm{~g} \mathrm{~kg}^{-1} \mathrm{ka}\right)$. Koerehun kuidun koostumus suunniteltiin monipuoliseksi, mutta erityisesti liukoisen kuidun määrää nostettiin koerehussa verrattuna kontrollirehuun.

Osa emakoista saapui imetysosastolle vasta hyvin lähellä porsimisaikaa, jopa porsimispäivänä, jolloin ne eivät ehtineet syödä imetysrehuja juuri ollenkaan ennen porsimista. Kuitupitoinen imetysrehu (koerehu) ei ehtinyt luultavasti vaikuttaa sonnan koostumukseen ja ummetukseen porsimisen yhteydessä kaikilla emakoilla. Emakoiden porsimisen jälkeinen ensimmäinen sonta tuli 1-2 päivän sisään porsimisesta 55\%:1la kontrolli- ja 48\%:1la koerehuryhmien emakoista. Kontrolliryhmän emakoilla oli kuitenkin enemmän ummetusta/kovaa sontaa porsimisen jälkeisinä päivinä, jolloin imetysrehuja oli jo syöty useampi päivä. Tämä saattoi johtua vähemmästä kuidun määrästä näiden emakoiden rehussa verrattuna koeryhmän emakoihin.

Aikaisemmissa tutkimuksissa on todettu runsaasti kuitua sisältävän tiineysrehun edistävän emakon normaalin imetysrehun syöntiä porsimisen jälkeen (Guillemet ym. 2010). Myös kuitupitoisen imetysrehun syönnin on näytetty lisääntyneen kuitupitoisen tiineysrehun käytön jälkeen kuidun ruuansulatuskanavan kapasiteettia ja toimintaa parantavan vaikutuksen vuoksi (Matte ym. 1994, Veum ym. 2009). Tässä tutkimuksessa emakot olivat saaneet tiineysaikana normaalia tiineysajan rehua, jossa raakakuitupitoisuus oli noin 7\%. Tiineysrehun kuidun lähteet eivät kuitenkaan olleet täysin samoja, kuin imetysrehussa, jolloin emakoiden ruuansulatuskanava ei ollut tottunut imetysrehuissa testattuihin kuitulisiin ja niiden hyväksikäyttöön sekä suurempaan kuitumäärään. Tämä saattoi korostua vanhemmilla emakoilla, mikä selittäisi suuremman silavan menetyksen viidettä kertaa porsineilla emakoilla ja vähäiset tai olemattomat erot ruokintakäsittelyiden välillä muissakin tuotantotuloksissa kaikilla emakoilla.

Emakoiden tuotantotulokset olivat tutkimustilalle tyypillisiä ja Suomen tämän hetkisten tilojen keskiarvoon verrattuna erittäin hyviä. Aikaisemmissa tutkimuksissa imetysaikana kuitupitoisella rehulla olleet emakot ovat syöneet enemmän rehua ja juoneet enemmän vettä verrattuna kontrollirehulla olleisiin emakoihin, mikä on lisännyt porsaiden painoa (Veum ym. 2009 ja Matte ym. 1994). Tässä tutkimuksessa emakoille tasattiin noin 14 porsasta ensimmäisen kolmen päivän aikana porsimisesta. Kahden viikon kuluttua porsimisesta ja vieroituksessa porsaita oli keskimäärin 13 emakkoa kohti molemmissa ruokintaryhmissä. Porsaiden painoissa ja kasvuissa ei ollut eroja ruokintaryhmien välillä. Emakoiden kuitupitoinen rehu imetysaikana ei siten tässä tutkimuksessa vaikuttanut porsaiden kasvua ainakaan heikentävästi. Se ei myöskään heikentänyt porsastuotannon 
taloudellista nettotuottoa. On kuitenkin huomioitava, että tuottojen vaihtelu on suurta, eikä koe- ja kontrollikäsittelyjen tulosten välillä havaittu tilastollisesti merkitseviä eroja.

\section{Johtopäätökset}

Rehukäsittelyiden välinen ero oli niin pieni tai havaintojen määrä liian vähäinen ja hajonta suuri, jotta olisi pystytty osoittamaan että kuitupitoinen rehu olisi parempi, huonompi tai vähintään yhtä hyvä imettävien emakoiden ruokinnassa. Hajonta ja poikkeavina tai epäselvinä poistettavien havaintojen määrä oli suurempi kuin mihin aiempien tutkimuslaitoksella tehtyjen tutkimusten perusteella oli varauduttu. Tällä tutkimuksella ei siis voida luotettavasti osoittaa, että runsaskuituinen ruokinta olisi parempi tai vaihtoehtoisesti ei olisi ainakaan huonompi kuin perinteinen emakoiden imetysajan ruokinta. Jotta voitaisiin luotettavasti ja tutkittuun tietoon nojaten sanoa, että runsaskuituisella ruokinnalla päästään vastaavin tuotantotuloksin korkeatuottoisten emakoiden imetysajan ruokinnassa, tulisi tehdä jatkotutkimuksia suuremmalla otoskoolla tai tarkentamalla tutkimusasetelmaa, mikä lisää tutkimuksen kustannuksia vaatiessaan pitemmän tutkimusajan ja enemmän henkilöstöä. Tulokset viittaavat siihen, että kuitupitoisella rehulla ruokittuna porsastuotanto on mahdollista järjestää taloudellisesti mielekkäästi, kunhan kuidun lähteenä toimivat rehut ovat riittävän edullisia. Tutkimus osoitti kuitenkin, että emakkokoetoiminta sikatilalla on mahdollista. Tutkimuksessa havaittiin, että tutkimustoiminta vaatii kehitystyötä sekä tilalta, tutkijoilta että laitevalmistajilta.

\section{Kiitokset}

Kiitos Euroopan Maaseudun Maatalouden Kehittämisrahastolle ja A-Tuottajat Oy:lle tutkimuksen taloudellisesta mahdollistamisesta. Erityiset kiitokset sikatalousyrittäjälle työntekijöineen tutkimuksen käytännön toteutuksesta ja hyvästä yhteistyöstä.

\section{Kirjallisuus}

Che, L., Feng, D., Wu, D., Fang, Z., Lin, Y. \& Yan, T. 2011. Effect of dietary fibre on reproductive performance of sows during the first two parities. Reproduction in Domestic Animals 46:1061-1066. https://doi.org/10.1111/j.1439-0531.2011.01787.x

Guillemet, R., Guérin, C., Richard, F., Dourmad, J.Y. \& Meunier-Salaün, M.C. 2010. Feed Transition between gestation and lactation is exhibited earlier in sows fed a high-fiber diet during gestation. Journal of Animal Science 88: 2637-2647. https://doi.org/10.2527/jas.2009-2307

Luke 2015. Rehutaulukot ja ruokintasuositukset. Märehtijät - Siat- Siipikarja - Hevoset. Luonnonvara- ja Biotalouden tutkimus 3/2015. 218 s.

Matte, J.J., Robert, S., Girard, C.L., Farmer, C. \& Martineau, G.-P. 1994. Effect of bulky diets based on wheat bran or oat hulss on reproductive performance of sows during their first two parities. Journal of Animal Science 72: 1754-1760. https://doi.org/10.2527/1994.7271754x

Oliviero, C., Kokkonen, T., Heinonen, M., Sankari, S. \& Peltoniemi, O.A.T. 2009. Feeding sows with high fibre diet around farrowing and early lactation: Impact on intestinal activity, energy balance related parameters and litter performance. Research in Veterinary Science 86: 314-319. https://doi.org/10.1016/j.rvsc.2008.07.007

Oliviero, C., Heinonen, M., Valros, A. \& Peltoniemi, O.A.T. 2010. Environmental and sow-related factors affecting the duration of farrowing. Animal Reproduction Science 119: 85-91. https://doi.org/10.1016/j.anireprosci.2009.12.009

Ramonet, Y., Meunier-Salaün, M.C. \& Dourmad, J.Y. 1999. High-fiber diets in pregnant sows: Digestive utilization and effects on the behavior of the animals. Journal of Animal Science 77: 591-599.

https://doi.org/10.2527/1999.773591x

Sarandan, H., Neufeld, N. \& Neufeld, K. 2008. Effects of a new lignocellulose product for fibre supplementation on MMA symptoms, reproductive performance and faecal quality in a pig farm with evident MMA problems in Romania. Lucrări Științifice Medicină Veterinară Vol. XLI, 2008, Timișoara.

Stroup, W.W, 2013. Generalized linear mixed models, modern concepts, method and applications. Chapman \& Hall/CRC, London. 
Tabeling, R., Schwier, S., \& Kamphues, J. 2003. Effects of different feeding and housing conditions on dry matter content and consistency of faeces in sows. Journal of Animal Physiology and Animal Nutrition 87: 116121. https://doi.org/10.1046/j.1439-0396.2003.00423.x

Veum, T.L., Crenshaw, T.D.M, Cromwell, G.L., Easter, R.A., Ewan, R.C., Nelssen, J.L., Miller, E.R., Pettigrew, J.E., Ellersieck, M.R. \& the North Cemtral Region-42 Committee on Swine Nutrition 2009. The addition of ground wheat straw as a fiber source in the gestation diet of sows and the effect on sow and litter performance for three successive parities. Journal of Animal Science 87: 1003-1012. https://doi.org/10.2527/jas.2008-1119 